\title{
HEPATOPROTECTIVE PROPERTIES OF SELECTED PLANTS AGAINST PARACETAMOL- INDUCED HEPATOTOXICITY IN MICE
}

Rajendra Gyawali, Amita Shrestha, Ashma Khanal, Jyoti Sharma Pyakurel, Nishchhal Joshi, Pankaj Bajaj, Pushparaj Chaudhary, and Roshni Thapa

Journal of Institute of Science and Technology

Volume 22, Issue 1, July 2017

ISSN: 2469-9062 (print), 2467-9240 (e)

\section{Editors:}

Prof. Dr. Kumar Sapkota

Prof. Dr. Armila Rajbhandari

Assoc. Prof. Dr. Gopi Chandra Kaphle

JIST, 22 (1): 147-151 (2017)

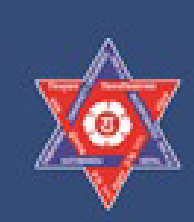

Inste 1

Jaly 2017

JOURNAL OF INSTITUTE OF

SCIENCE AND TECHNOLOGY

Published by:

Institute of Science and Technology

Tribhuvan University

Kirtipur, Kathmandu, Nepal 


\title{
HEPATOPROTECTIVE PROPERTIES OF SELECTED PLANTS AGAINST PARACETAMOL-INDUCED HEPATOTOXICITY IN MICE
}

\author{
Rajendra Gyawali*, Amita Shrestha, Ashma Khanal, Jyoti Sharma Pyakurel, Nishchhal Joshi, \\ Pankaj Bajaj, Pushparaj Chaudhary, and Roshni Thapa \\ Department of Pharmacy, Kathmandu University, Dhulikhel, Kavre, Nepal \\ "Corresponding E-mail: ragyawali@gmail.com
}

\begin{abstract}
The hepatoprotective properties of the ethanolic extracts of Punica granatum peels, Crataeva religiosa leaves and Jasminum polyanthrum leaves were evaluated for the paracetamol induced liver toxicity in mice. Antioxidant, cytotoxicity and phytochemical screening were carried out to assure the therapeutic efficacy of these plants. Oral administration of plant extracts for 7 days in mice significantly reduced the impact of paracetamol toxicity on the serum markers of liver damage, aspartate transaminase (AST), alanine transaminase (ALT) and total protein. The extract showed significant hepatoprotective effects as evidenced by decreased serum enzyme activities like ALT, AST and changed total protein. The phytochemical and antioxidant studies also supported that plant extract markedly reduced the toxicity due to presence of antioxidant phytochemicals. The result suggests that Jasminum polyanthrum is potent hepatoprotective agent against paracetamol induced hepatotoxicity in mice.
\end{abstract}

Key words: Plants, Antioxidant, Hepatoprotective, Enzyme, Protein.

\section{INTRODUCTION}

Natural remedies from medicinal plants are considered to be effective and safe alternative treatments for hepatotoxicity. Over the past decades, herbal medicines have garnered growing attention as potential therapeutic agents to prevent and treat liver disease (Yao et al., 2016). These herbal sources have shown the ability to maintain the normal functional statues of liver. In Nepal, more than 100 medicinal plants are ethnomedicinally used in the preparations of liver remedies (Baral \& Kurmi, 2006). Liver protective plants contain complex chemical constituents with multi-level and multi-target pharmacological activity. The development of plant based hepatoprotective drugs has been given importance in accordance with the composition principles of herbs (Sharma et al., 1991). The efficacy of such plants has been previously explored by various researchers for their hepatoprotective and immunomodulatory activities (Ilyas et al., 2016).

The liver plays an astonishing array of vital functions in the maintenance, performance and regulating homeostasis of the body. It is involved with almost all the biochemical pathways. Most of the hepatotoxic chemicals damage liver cells mainly by lipid peroxidation and other oxidative damages (Dianzai et al., 1991). High dose of paracetamol is one of the factors for hepatic necrosis that can result in the liver failure. Some researches have been carried out on the hepatoprotective property of Punica granatu (Celik et al., 2009) and Crataeva religiosa (Jaikanth et al., 2015). But similar studies in plants originated from Nepal have not been done. Therefore, in the present study, efficacy of the plants was studied on biochemical and pharmacological parameters with an objective to ameliorate the liver disease induced by the paracetamol.

\section{MATERIALS AND METHODS}

\section{Plants material}

The peels of Punica granatum, leaves of Crataeva religiosa and leaves of Jasminum polyanthrum were collected. Plant materials were identified by botanist and herbarium specimen was deposited in the Department of Pharmacy, Kathmandu University. Samples were washed, dried under shade and powdered to coarse. The powdered material was extracted with alcohol ( $80 \%$ ethanol) in Soxhlet apparatus for $48 \mathrm{hrs}$. For oral administration, extracts were dissolved in distilled water. 


\section{Phytochemical Screening}

The crude methanolic extracts of the barks of different plants were screened to detect the presence of phytochemicals, as per the standard screening procedure (Trease \& Evans 1996).

\section{DPPH radical scavenging assay}

The DPPH radical scavenging activity of extracts was determined using the method of BrandWilliams et al. (1995) with some modifications. Briefly, test samples were prepared by adding $3 \mathrm{ml}$ of $100 \mu \mathrm{mol}$ methanolic DPPH solution in $3 \mathrm{ml}$ methanolic plant extract solution of varying concentrations $(2,4,6,10 \mu \mathrm{g} / \mathrm{ml})$. Corresponding blank sample was prepared by adding $3 \mathrm{ml}$ plant methanolic extract and $3 \mathrm{ml}$ of methanol. Mixer of $3 \mathrm{ml}$ methanol and $3 \mathrm{ml} \mathrm{DPPH}$ solution was used as control. All these mixtures were immediately kept in dark to protect from light and were allowed to react. After 30 minutes, absorbance was noted at $517 \mathrm{~nm}$ using UV-visible spectrophotometer.

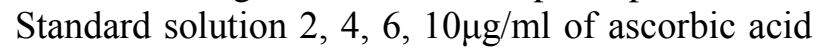
was prepared from stock solution.

\section{Brine shrimp Lethality Test}

Ethanolic extract of the samples were evaluated for lethality to Brine shrimp larvae (A. salina Leach) according to the published procedure (Meyer et al., 1982). Brine shrimp eggs were suspended for 48 hours in a conical flask containing $300 \mathrm{ml}$ of artificial seawater for hatching (the eggs). The flasks were well aerated with the aid of an air pump, and kept in a water bath at $29-30^{\circ} \mathrm{C}$. The extracts were dissolved in $1 \%$ aqueous DMSO, and then in sea water to obtain a concentration of 1000 ppm, 500 ppm, 250 ppm, 100 ppm, 50 ppm, 25 $\mathrm{ppm}$ and $10 \mathrm{ppm}$. An aliquot of each concentration (1 ml) was transferred, in triplicate, into clean sterile vials with pipette, and aerated seawater (9 $\mathrm{ml}$ ) was added. Ten Brine shrimp nauplii were transferred to each vial. $1 \%$ DMSO in seawater was used as negative control. After 24 hours, the numbers of survivors were counted, and the mortality percentage was calculated. The lethal concentration for $50 \%$ mortality after 24 hours of exposure, the chronic LC50 and 95\% confidence intervals were determined by using the Probit method as the measure of toxicity of the extract or fractions. The extracts were considered as toxic at LC $_{50}$ less than $10 \mu \mathrm{g} / \mathrm{ml}$ (Setzer et al., 2001).

\section{Animals}

Inbred Swiss albino mice weighing $20-30 \mathrm{~g}$ of either sex, bred in Central Animal House, Kathmandu University, Department of Pharmacy were procured and used for the study. The animals were fed food pellets and water ad libitum. Animals were maintained in standard lab conditions $(12 \mathrm{~h}$ : $12 \mathrm{~h}$ dark and light cycle at $25 \pm 2{ }^{\circ} \mathrm{C}$ temperature). The study was approved by the Institute Animal Ethics Committee, Kathmandu University, Dhulikhel.

\section{Hepatoprotective activity}

The treatments of mice were categorized under 6 groups, each comprising six animals.

Group 1: Control group with aqueous vehicle for 7 days.

Group 2: $\quad$ Paracetamol $(250 \mathrm{mg} / \mathrm{kg})$ on 7 th day only.

Group 3: Silymarin (extracted from the Silybum marianum) $(500 \mathrm{mg} / \mathrm{kg})$ for 7 days + Paracetamol $(250 \mathrm{mg} / \mathrm{kg})$ on 7 th day

Group 4: Pomegranate extract $(200 \mathrm{mg} / \mathrm{kg})$ for 7 days + Paracetamol (250 $\mathrm{mg} / \mathrm{kg}$ ) on 7 th day.

Group 5: Crataeva extract $(200 \mathrm{mg} / \mathrm{kg})$ for 7 days + Paracetamol $(250 \mathrm{mg} / \mathrm{kg})$ on 7 th day.

Group 6: Jasmine extract $(200 \mathrm{mg} / \mathrm{kg})$ for 7 days + Paracetamol $(250 \mathrm{mg} / \mathrm{kg})$ on 7 th day.

\section{Collection of blood and biochemical analysis}

On the 9th day, all the animals were sacrificed by mild ether anesthesia. About $0.5 \mathrm{ml}$ of blood was drawn from each mouse and transferred to separate vials. All the blood samples were kept in a container containing icepacks and then taken to the laboratory for the biochemical estimation of alanine aminotransferase (ALT), Aspartate aminotransferase (AST) and total protein (Babson et al., 1966).

\section{Toxicity evaluation}

The acute oral toxicity study of the extracts was carried as per the Organisation for Economic Cooperation and Development (OECD 420) guidelines. Administration of the extracts stepwise up to the dose $200 \mathrm{mg} / \mathrm{kg}$ in aqueous vehicle 20 $\mathrm{ml} / \mathrm{kg}$ of body weight caused no considerable signs of toxicity in the tested animals.

\section{RESULTS AND DISCUSSION}

\section{Phytochemical screening of the plants}

The randomly selected plants subject to phytochemical screenings were found to contain different metabolites viz. alkaloids, tannin, flavonoids, terpenoids, resin and glycosides. 


\section{Antioxidant activity}

The effect of plant extracts on antioxidant property showed that, Jasmine extract showed strongest antioxidant activity with $\mathrm{IC}_{50} 0.73$. Pomegranate extract was also found equally strong in comparison to standard i.e. ascorbic acid. Liver damage causes and releases the enzymes ALT, AST and total protein in the serum due to the membrane and cellular damages of the liver. Paracetamol is a hepatotoxin which induces the liver damage by affecting the metabolic functions. The liver enzyme level concentration was increased in serum due to the toxic effect of paracetamol. The decrease in liver enzyme levels in serum is due to the protective effect of given plant extracts on liver cells followed by restoration of membrane permeability (Sethuraman, 2003). Phenol compounds are responsible for hepatoprotective and antioxidant activity of plant extracts (Singh et al., 1993). They exhibit antioxidant activity by inactivating lipid free radicals or preventing decomposition of hydroperoxides into free radicals.

Table 1. Antioxidant property extracts in terms of IC50 value.

\begin{tabular}{|l|c|c|c|c|}
\hline \multirow{2}{*}{ Parameter } & \multicolumn{3}{|c|}{ Groups } \\
\cline { 2 - 5 } & Ascorbic acid & \multicolumn{1}{|c|}{ Pomegranate } & Jasmine & Crataeva \\
\hline $\begin{array}{l}\text { IC50 value } \\
(\mathrm{mcg} / \mathrm{ml})\end{array}$ & 6.29 & 5.86 & 0.73 & 10.74 \\
\hline
\end{tabular}

\section{Biochemical characterization}

The present study was performed to assess the hepatoprotective activity of various extracts of Punica granatum, Crataeva religiosa and Jasminum polyanthrum in mice against paracetamol as hepatotoxin which cause liver damage. Altering liver microsomal membranes of hepatocytes and cell damage results in release of enzymes AST, and ALT. Levels of AST, ALT and total protein in serum used to assess hepatic function in mice were changed (Table 2). The hepatic enzymes were significantly controlled by plant extracts. Among the 6 groups, ethanolic extract of Jasmine and Creativa have effectively controlled the liver damage by restoration of the levels of liver function. The level of ALT, AST and total protein was found to be significantly improved in comparison to paracetamol treated mice. Similar result on Jasmine was found in a recent study (Shekhar \& Prasad, 2015).

Table 2. The levels of ALT, AST, and total protein in different groups of mice.

\begin{tabular}{|l|c|l|l|l|l|c|}
\hline \multirow{2}{*}{ Parameters } & \multicolumn{5}{|c|}{ Groups } \\
\cline { 2 - 7 } & \multicolumn{1}{|c|}{ Control } & Paracetamol & \multicolumn{1}{|c|}{ Silymarin } & Pomegranate & \multicolumn{1}{c|}{ Crataeva } & Jasmine \\
\hline ALT (IU/l) & $48.6 \pm 26.8$ & $250.2 \pm 37.65$ & $170.8 \pm 14.25$ & $204.4 \pm 14.51$ & $155 \pm 33$ & $151.4 \pm 46.74$ \\
\hline AST (IU/l) & $130 \pm 59.83$ & $299.60 \pm 73.73$ & $112.2 \pm 12.37$ & $220.2 \pm 20.21$ & $196.6 \pm 37.65$ & $204.8 \pm 24.91$ \\
\hline $\begin{array}{l}\text { Total protein } \\
(\mathrm{gm} \%)\end{array}$ & $5.24 \pm 1.24$ & $6.28 \pm 1.06$ & $8.44 \pm 1.59$ & $4.74 \pm 0.69$ & $5.28 \pm 0.75$ & $7.52 \pm 1.08$ \\
\hline
\end{tabular}

\section{Brine Shrimp Lethality Test}

Based on the Brine shrimp bioassay analysis, the $\mathrm{LD}_{50}$ value of the Crataeva plant was found to be strong while Pomegranate and Jasmine were similar (Table 3). Though these plants are edible, they were found to be toxic during Brine shrimp assay. But after the administration of extracts at the dose of $200 \mathrm{mg} / \mathrm{kg}$ in mice, they did not show any toxicity in vivo.
Table 3. The cytotoxicity of plant extracts in Brine shrimp larvae.

\begin{tabular}{|l|l|l|l|}
\hline \multirow{2}{*}{ Parameters } & \multicolumn{3}{|c|}{ Groups } \\
\cline { 2 - 4 } & Pomegranate & Crataeva & Jasmine \\
\hline LD50 $(\mathrm{ug} / \mathrm{m})$ & 3.58 & 2.52 & 3.025 \\
\hline
\end{tabular}

The result of DPPH assay indicates that these plants possessed good anti-oxidant properties. Administration of $200 \mathrm{mg} / \mathrm{kg}$ of each extract has 
shown no toxicity in mice. Statistical analysis of the enzyme levels in the mice was significant in producing hepato-protective action. The levels of ALT and AST were reduced significantly in extract treated groups and the effect is comparable to that of standard drug treatment with extracts decreased the serum levels of ALT and AST towards the respective values. This is an indication of stabilization of plasma membrane as well as repair of hepatic tissue damage caused by paracetamol. The above changes can be considered as an expression of the functional improvement of hepatocytes, which may be caused by an accelerated regeneration of parenchymal cells. Protein metabolism is a major role of liver and healthy functioning of liver is required for the synthesis of the serum proteins except the gammaglobulins. Hypoproteinemia is a feature of liver damage due to significant fall in protein synthesis (Kanchana \& Sadi, 2011). Hypoproteinemia was observed after paracetamol ingestion but the trend turned towards normal in pomegranate and crataeva extract treated mice. Some researchers have carried out the hepatoprotective property of Punica granatum and revealed that constituents present in plant impart protection against carcinogenic chemical induced oxidative injury that may result in development of cancer during the period of a 52day protective exposure (Celik et al., 2009). In another study, Crataeva religiosa was found to significantly restore hepatoprotective enzymes (Jaikanth et al., 2015). This restoring effect of the extracts indicate that the phytochemicals present in extracts such as flavonoids, tannins and terpenoids might have acted in a coherent manner to neutralize the toxicity of paracetamol and also they may have exhibited a stabilizing effect on the plasma membranes of hepatocytes to restore the levels of serum enzymes. On the basis of ALT level, which is more specific to the liver, Jasmine plant was found to possess significant hepatoprotective property.

\section{ACKNOWLEDGEMENT}

Authors would like to acknowledge to Department of Pharmacy, Kathmandu University for supporting this research project.

\section{REFERENCES}

Babson, A. L.; Greeley, S. J.; Coleman, C. M. and Philips, G. D. (1966). Phenolphthalein monophosphate as a substrate for serum alkaline phosphatase. Clinical Chemistry, 12: 482-490.

Baral, S. R. and Kurmi, P. P. (2006). A compendium of medicinal plants in Nepal . Publisher: Mrs. Rachana Sharma, 281 Maiju Bhal, Chabahil, Kathmandu, Nepal.

Brand-Williams, W.; Cuvelier, M. E. and Berset, C. (1995). Use of a free radical method to evaluate antioxidant activity. Lebenson Wiss Technology, 28: 25-30.

Celik, K.; Temur, A. and Isik, I. (2009). Hepatoprotective role and antioxidant capacity of pomegranate (Punica granatum) flowers infusion against trichloroacetic acidexposed in rats. Food Chemistry and Toxicology, 47 (1): 145-149.

Dianzai, M. U.; Muzia, G.; Biocca, M. E. and Canuto, R. A. (1991). Lipid perioxidation in fatty liver induced by caffine in rats. International Journal of Tissue Reactions, 13: 79-85.

Ilyas, U.; Katare, D. P.; Aeri, V. and Naseef, P. P. (2016). A review on hepatoprotective and immunomodulatory herbal plants, 10: 19, 66-70.

Jaikanth, C. M.; Venkateswaran, K. V.; Selvasubramanian, S. and Sesh, P. S. L. (2015). Effect of Extracts of Crataeva religiosa on Hepatic Markers in Liver Intoxication. Indian Veterinary Journal, 92 (9): 86-88.

Kanchana, N. and Sadi, A. M. (2011). Hepatoprotective effect of Plumbago zeylanica on paracetamol induced liver toxicity in rats. International Journal of Pharmacy and Pharmaceutical Sciences, 3 (1): 151-154.

Meyer, B. N.; Ferrigni, N. R.; Putnam, J. E.; Jacobsen, L. B.; Nichols, D. E. and McLaughlin, J. L. (1982). Brine Shrimp: A convenient general bioassay for active plant constituents. Planta Medica, 45: 31-34.

Sethuraman, M. G.; Lelitha, K. G. and Kapur, B. R. (2003). Hepatoprotective activity of Sarcostemma brevistigma against $\mathrm{CCl} 4$ induced hepatic damage in rats. Current Science, 84: 1186-1197.

Setzer, M. C.; Setzer, W. N.; Jackes, B. R.; Gentry, G. A. and Moriarity, D. M. (2001). The medicinal value of tropical rainforest plants from Paluma, North Queensland, Australia. Pharmaceutical Biology, 39: 67-78. 
Sharma, A.; Chakraborti, K. K. and Handa, S. S. (1991). Antihepatotoxic activity of some Indian herbal formulations as compared to silymarin. Fitoterapia, 62: 229-235.

Shekhar, S. and Prasad, M. P. (2015). Comparative analysis of antioxidant properties of jasmine species by hydrogen peroxide assay. European Journal of Biotechnology and Bioscience, 3(2): 26-29.

Singh, B.; Saxena, A. K.; Chandan, B. K.; Agarwal, S. G.; Bhatia, M. S. and Anand, K. K.
(1993). Hepatoprotective effect of ethanolic extract of Eclipta alba on experimental liver damage in rats and mice. Phytotherapy Research, 7 (2):154-158.

Trease, G. E. and Evans, W. C. (1996). Pharmacognosy. Alden Press, Oxford, UK.

Yao, H.; Qiao, Y. J.; Zhao, Y. L.; Tao, X. F.; Xu, L. N.; Yin, L. H.; Qi, Y. and Peng, J. Y. (2016). Herbal medicines and nonalcoholic fatty liver disease. World Journal of Gastroenterology, 22 (30): 6890-6905. 